\title{
Russian mission to Mars expected to be held back for two years
}

\begin{abstract}
Washington. Russian managers of the Mars 94 planetary mission are reported to have given up hope that the spacecraft can be launched in October as planned and are expected to announce soon that the mission has been delayed until 1996.

Planning for the Mars 94 project, which began in the 1980 s and eventually involved scientists from 20 countries, would have sent an orbiter, two small landers and two surface penetrators to investigate Mars. Since then, however, the project
\end{abstract} has fallen victim to financial, technical and scheduling problems.

Last year, funding by the Russian government was held up for so long that spacecraft builders could not pay their subcontractors, and work slowed down. By the time the money was restored at the end of the year and work resumed, "the schedule had zero contingency in it", according to Louis Friedman of the Planetary Society, which is based in the United States.

There were technical delays as well, notably with the German-built Argus platform for pointing the spacecraft's cameras. Earlier this year, project managers considered launching in October anyway, even if all the instruments were not ready in time. Now, that plan has also been abandoned.

Instead, the launch will be postponed until the next Mars 'window' in 1996. Another Russian mission originally planned for that slot, to include a French-built balloon experiment and a rover vehicle for exploring the Martian surface, has been pushed to 1998 .

But these plans may also unravel. The 1996 opportunity requires more launch energy than this year's, and this means that the Mars 94 instrument payload will probably have to be split into two launches, according to Roald Sagdeev, a former director of the Soviet planetary programme who is now with the East-West Science and Technology Center at the University of Maryland.

In such circumstances, he says, some of the instruments from the 1998 mission could fly in 1996, although the French balloon experiment may not be ready by then.

Friedman, whose society is involved in the 1998 balloon and rover experiments, believes the Russians will have enough money to launch some kind of Mars mission in 1996. "On the Russian side they may ironically have less of a problem in this regard than the Western partners," he says, as funding for Mars 94 has already been

committed by the Russian government.

In fact, one reason for delaying the official announcement of the mission's postponement has been to get as much work finished this year as possible. With inflation in Russia running at 10-20 per cent a month, funds appropriated last year buy less and less with each passing day.

But keeping engineering and science teams together for another two years is a more serious problem. Sagdeev estimates

\section{IMAGE UNAVAILABLE FOR COPYRIGHT REASONS}

veyor series, which would encourage the Russian government to keep supporting it.

Cooperative agreements with the United States have already introduced substantial stability into the Russian space programme. Working groups between the two countries are discussing possible joint projects, which could include missions to explore Mars, Pluto and the Sun.

But, after 30 years, the era of Russian-led planetary missions appears to be drawing to a close. At a recent symposium at Johns Hopkins University, Sagdeev detailed how things have changed for the once-exalted Russian space programme. Whereas the VEGA missions that visited Venus and Halley's comet in the 1980 s cost only $\$ 55$ million for two spacecraft, the single-shot Mars 94 was priced at $\$ 200$ mil-

that IKI, the Russian Space Research Institute, has already lost 20 to 30 per cent of its staff. If no more money is forthcoming from the government for space missions, engineers at the Lavochkin organization that builds the spacecraft, as well as its suppliers, would have to close shop and search for other work.

The only salvation for the Russian space programme may be in cooperation with the United States. Sagdeev and others hope that the Russian 1998 Mars mission can be coordinated with NASA's planned Mars Sur-

mission.

lion. Proton rocket launches that used to cost Russian scientists only $\$ 2.5$ million now go for 10 times that much.

Perhaps worst of all, says Sagdeev, the Russian space programme, stripped of its Cold-War aura, now has to compete with other disciplines for funding. After years of special treatment, he said, space scientists could be forced to go back to join the "traditional, conventional science community"; and that, he warned, would have a "tremendous negative impact".

Tony Reichardt

\section{UK council backs peer review shift}

London. Britain's new Engineering and Physical Sciences Research Council (EPSRC) has given its approval in principle to a more streamlined system for assessing grant applications

Council officials say that the proposed changes, which they hope will receive final approval at the council's next full meeting in June, will reduce the amount of time and paperwork involved, as well as ensuring that research projects are more closely aligned with the stated 'mission' of the council

But some scientists remain worried over the extent to which the changes will impose a heavy liability on programme managers who may have little first-hand experience of the research for which they are responsible.

Under the system operated by the EPSRC's predecessor, the Science and Engineering Research Council (SERC), grant applications were approved through a hier- archy of peer-review committees. Smaller grants were awarded directly by disciplinebased panels and subcommittees, but larger grants required the additional approval of committees sitting above them; grants worth more than $£ 1$ million required the approval of the whole council.

Two factors have determined the proposed change in strategy. One has been a desire, actively encouraged by the Office of Science and Technology, to reduce administrative costs associated with the review of grant applications, and increase the efficiency with which applications are handled.

The second has been the need to fulfil a requirement imposed by last year's white paper on science that the research council should explicitly commit itself to increasing Britain's industrial competitiveness (and maintaining the quality of life).

A paper prepared by EPSRC officials 
and presented to council members at their first full meeting two weeks ago set out a strategy for addressing both issues by replacing the traditional system of peerreview committees with the new system.

Now, decisions on grant awards will be the responsibility of programme managers. Decisions will still be based on advice from scientific peer-review committees; but programme managers will also be expected to take into account input from other sources about how the research in question will meet the EPSRC's explicit mission.

The approach was agreed upon in principle by the council, although formal approval is being withheld until the council has been told how the new system will operate in practice - and, in particular, how the balance will in practice be struck between scientific and other criteria.

Officials of both the EPSRC and the OST have been taking pains to stress that the new system is not intended to replace the traditional peer-review system. William Waldegrave, the cabinet minister responsible for science, has said in a letter to the opposition science spokesman, Lewis Moonie, that peer review will remain a "key element" in determining the quality of basic science research proposals.

But Waldegrave also emphasized that grant applications will not be judged on scientific merit alone, and that attention will also be paid to the extent to which the research proposed is aligned with technological priorities identified, for example, by the Technology Foresight programme.

"The way that the SERC handled grant requests had certainly become very bureaucratic and time-consuming, with far too much micro-management by committees," says John Mulvey of the University of Oxford. "But if a lot of real responsibility is delegated to civil servants in the Swindon office [of the EPSRC], then many scientists will be watching this with caution."

EPSRC officials say that the new responsibilities of programme managers will be little different from those occupying similar positions in the US National Science Foundation (NSF). But British scientists point to the important difference that the US officials are frequently university scientists on secondment to the NSF, whereas their British counterparts are full-time civil servants.

Meanwhile, the Higher Education Funding Council for England (HEFCE) has published draft proposals of criteria it suggests using to allocate money to university departments to support "generic research" of potential interest to industry.

University departments will qualify for such extra funds, the HEFCE proposes, provided that they already receive research support of at least $£ 20,000$ a year from at least three different outside bodies.

The HEFCE has already decided that $£ 10$ million should be awarded to university departments for generic research in the next academic year.

\section{Scotland digs in over mooted shake-up of research labs}

Edinburgh. Centuries of ill-feeling between England and Scotland have resurfaced over a proposal by a group of civil servants that a number of Scottish research institutes be grouped together into new agencies "owned" either by the London-based Ministry of Agriculture Food and Fisheries (MAFF), or the Biotechnology and Biological Sciences Research Council (BBSRC).

The proposal is contained in the "emerging findings" of a review of government research laboratories being carried out by the Cabinet Office's Efficiency Unit currently circulating in Whitehall. It is one of several proposals designed to rationalize the organization of these laboratories by grouping them according to common interests (see Nature 368, 681; 1994).

The preliminary conclusion of the group, for example, is that all government research institutes in the United Kingdom relating to the marine environment might be placed in a single grouping "owned" by the Scottish Office, while those relating to food production be reorganized under MAFF, and more basic biological research to the BBSRC.

But some Scottish scientists are worried that, if accepted by the government, such proposals could undermine what is described as the "Scottish system" of research support. This is based on encouraging strong vertical links between institutes involved in basic and applied research, as well as horizontal links between those involved in different areas of science.

Others fear that, although the amalgamation proposed in the preliminary conclusions might lead to a more cost-effective use of research resources for Britain as a whole, it could result in funds being taken away from smaller Scottish institutes as resources are concentrated on larger institutions south of the border.

"The problem is that, looked at on a UK basis, Scottish institutions that play a useful role locally can be totally outweighed by bodies in the south", says Maxwell Irvine, principal of the University of Aberdeen, which is currently involved in a scheme linking several local institutions - such as the internationally known Rowett Research Institute and Macaulay Land Use Research Institute - into a joint research consortium.

"We would be very concerned if those who are playing national games [with the reorganization of research institutes] were to weaken what we see as a very positive regional development."

The dispute has also highlighted an apparent difference in research strategies between the Scottish Office, which is keen to play an active part in stimulating collaborative efforts by the private and public sectors, and the Cabinet Office in London, which is placing greater emphasis on reducing direct

\section{IMAGE UNAVAILABLE FOR COPYRIGHT REASONS}

Fish farming: a new research-based industry.

public support for innovation.

Last year, the Scottish Office's Agricultural and Fisheries Department published a policy statement suggesting an expansion of the Scottish system under a Scottish Biological Sciences Board.

Some fear that, if implemented, the scrutiny team's proposals could introduce new vertical and horizontal distinctions between institutes that would cut directly across the Scottish Office's attempts to build an integrated system of research support.

Jean Balfour, a former chairwomen of the Scottish Countryside Commission, warns that such a move would be "extremely destructive to the whole question of how research is carried out in Scotland".

At the same time, the dispute has fanned a more widespread disenchantment in Scotland with some of the policies of the Conservative government, particularly since cuts in public spending have frequently hit those areas in which Scotland has benefited substantially from its membership of the United Kingdom in the past.

At a meeting in Edinburgh last month organized by the Royal Society of Edinburgh as part of the Edinburgh Science Festival, for example, Bruce Pattullo, the governor and chief executive officer of the Bank of Scotland, warned that privatization - one of the government's main policy objectives - "is about maximizing short term cash returns to the Treasury, and not about maximizing competition".

William Waldegrave, the cabinet minister responsible for science, has promised that the final version of the scrutiny team's report will be made available for public comment before any of its recommendations are acted on by the government. Several Scottish research institutes are said to be sharpening their pens in readiness.

David Dickson 